\title{
Can we elevate the subsiding coastal plain of the Netherlands with controlled sedimentation?
}

\author{
Kay Koster, Jan Stafleu, Peter C. Vos, and Michiel J. van der Meulen \\ TNO Geological Survey of the Netherlands, dept. Geomodelling, Utrecht, 3584 CB, the Netherlands \\ Correspondence: Kay Koster (kay.koster@tno.nl)
}

Published: 22 April 2020

\begin{abstract}
Half the surface area of the coastal plain of the Netherlands has been subsiding below mean sea-level as a result of peatland drainage. At present, the low elevation is sustained, because sedimentation necessary to aggrade the coastal plain back to natural elevations is hampered by engineering structures. Alternatively, controlled sedimentation is a discussed method to elevate the coastal plain. This can either be achieved by allowing water courses to deliver sediments to designated areas, or by anthropogenic deposition.

Here, we assess the possibilities of this strategy by determining whether natural systems or anthropogenic deposition are sufficient to elevate the surface to mean high water (MHW), taking into account IPCC projected minimum and maximum forecasted sea-level rise (RCP2.6 and RCP8.5), and predicted future subsidence. We use the 3D geological subsurface model GeoTOP to quantify sediments; i.e. clay and sand that were naturally delivered to the coastal plain by series of tidal inlets and the Rhine river system. Furthermore, we quantify the amount of anthropogenic deposition, and analyze documented supplies. Finally, we discuss the implications of controlled sedimentation in designated areas by providing examples of past embankment breaches.

We quantify that $16.98 \mathrm{~km}^{3}$ of sediments are required to elevate the surface to $\mathrm{MHW}$, and between 22.41 and $29.29 \mathrm{~km}^{3}$ at the end of the $21 \mathrm{st}$ century. We estimate that $45.30 \mathrm{~km}^{3}$ of sediments were delivered by the tidal systems during 3000 years ( $52 \%$ sand), $20.18 \mathrm{~km}^{3}$ by the Rhine river system during 8000 years ( $29 \%$ sand), and $3.59 \mathrm{~km}^{3}$ of anthropogenic deposition.

We conclude that the coastal plain of the Netherlands cannot be elevated to more safe levels with controlled sedimentation. Exceptions are areas proximal to tidal systems with high sediment yields. Anthropogenic deposition, combining natural sedimentation with supplied sediments, or allowing peat growth in inundated areas could be viable alternatives as well as.
\end{abstract}

\section{Introduction}

Reduced sediment delivery prevents subsiding coastal plains from keeping their elevation at natural equilibrium levels (Jelgersma et al., 1993; Syvitski et al., 2009). This is often the result of large-scale engineering infrastructures such as dams and series of embankments that trap sediments (Walling, 2006; Rovira and Ibañez, 2007), or enhance sediment bypassing by routing, shortening or deepening water courses (Van der Meulen et al., 2006; Tang et al, 2008).

Sustaining low elevations of coastal plains evidently enhances flood risk (Reed, 1989; Li et al., 2004). This became especially clear in embanked populous areas where decades of subsidence increased accommodation space for flood wa- ter. Catastrophic consequences were for instance revealed when embankments breached in the Mississippi delta during hurricane Katrina in 2005 (Dixon et al., 2006). Furthermore, Auerbach et al. (2015) reported a severe flood after embankment breaching in a part of the Ganges-Brahmaputra delta in Bangladesh. Both cases resulted in the loss of life, land and infrastructure. However, the Ganges-Brahmaputra case showed that during the two years after the flood, newly delivered sediments were able to raise the land, making the area less prone to future flooding. Controlled delivery of sediments to designated areas within coastal plains is therefore often suggested as a measure to counteract subsidence (Blum and Roberts, 2009; Hijma et al., 2017), which can either be 


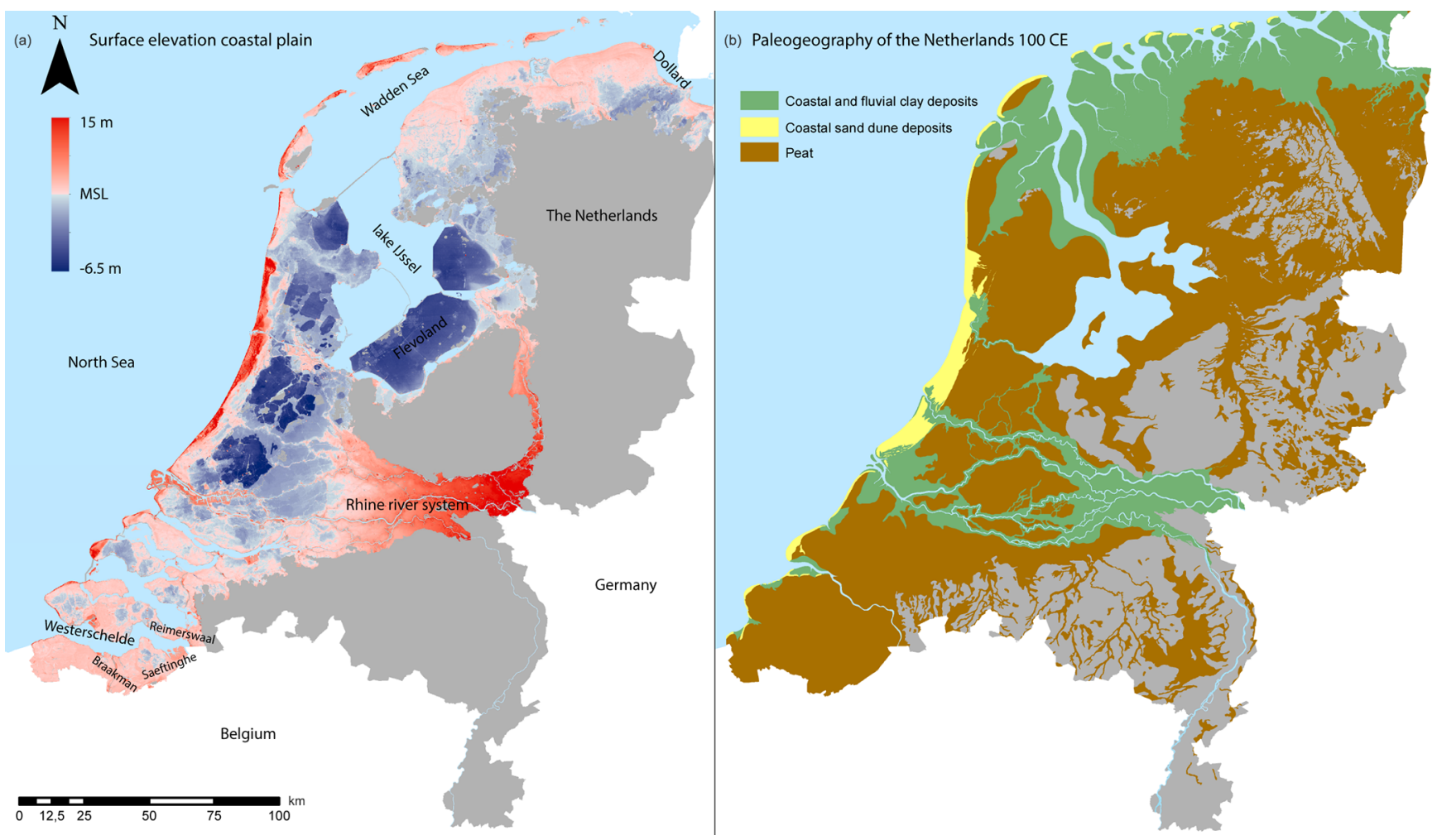

Figure 1. Maps showing: (a) The surface elevation of the coastal plain of the Netherlands and Rhine river system (@TNO Geological Survey of the Netherlands). Half the surface area of the coastal plain is situated below MSL. Provided geographical names are mentioned in this contribution. (b) Paleogeography of the Netherlands around 100 CE (Vos, 2015). Substantial parts of the coastal area are covered with peat that now largely disappeared by human activities. Sedimentation around $100 \mathrm{CE}$ merely took place around river channels and in the north (Wadden Sea). Grey areas represent deposits of pre-Holocene age.

achieved by reintroducing natural sedimentation, or by emplacing sediment.

The densely populated, peat-rich coastal plain of the Netherlands (ca. $17500 \mathrm{~km}^{2}$ ) is a prime example of a sediment-starved subsiding area (Fig. 1). Approximately $12 \%$ of the present day volume of Holocene deposits consists of peat (TNO-GSN, 2019), emphasizing that sediment starvation is inherent to this system (Erkens, 2009). Ca. 50\% of these lowlands have subsided below mean sea-level (MSL) due to centuries of phreatic groundwater level lowering, which causes sediment to compact and peat to oxidize, and by peat mining. To protect the subsiding plains against floods, they have been embanked from $1000 \mathrm{CE}$ onwards, which put an end to natural aggradation (Jelgersma et al., 1993): only breaching of embankments, may result in the delivery of some sediment to the otherwise sediment-starved lowlands (Vos, 2015).

The future use of embankments and other waterworks to protect the subsiding Dutch coastal plain has been debated since the 1970's (Waterman, 1991). Traditional floodprotection approaches may become unsustainable technically and financially when the Netherlands is subjected to at least another 2 to 4 centuries of sea-level rise (Jevrejeva et al.,
2012) and subsidence. For that reason, it has already been proposed to abandon the coastal plains, maintaining only selected areas, or even create new land seawards (Waterman, 1991). Alternatively, raising sections of the lowlands artificially was proposed as a measure to ensure the viability of the Netherlands in the next centuries (Van der Meulen et al., 2007). They concluded that $13.3 \mathrm{~km}^{3}$ of sediment would be required to compensate for sediment deficiency, and an additional of 59 to 72 million $\mathrm{m}^{3} \mathrm{yr}^{-1}$ to keep elevation of selected areas in pace with 21 st century predicted sea-level rise. Terpstra et al. (2007) introduced the ideas of dikes that are so wide that they assumedly cannot breach and are basically elongated mounds. Both ideas are essentially the same in the sense that they involve large-scale land raising, which requires substantial volumes of sediment.

Here, we further explore controlled deposition as a measure to counteract subsidence in the coastal plains of the Netherlands. We focus on two dominant depositional systems that delivered sediments prior to the embanking of the area: a complex of tidal systems (during ca. 3000 years) and the Rhine river fluvial system (during ca. 8000 years). We used information from the 3D geological subsurface model GeoTOP to quantify the amount and type of (i) natural de- 
posits of the Holocene tidal and river systems, and (ii) anthropogenic deposits which may be up to centuries old, but the bulk of which was emplaced after WW-II.

Erkens et al. (2006) previously quantified Holocene sediment storage for the entire fluvial system in the Netherlands. They found $16 \mathrm{~km}^{3}$ of fluvial sediments are stored of which $36 \%$ consist of sand and gravel. Although their study used similar borehole information and digital elevation models as GeoTOP, their spatial coverage is limited to the fluvial system and a small part of the adjacent coastal plain. Here, we extent their area to cover the full coastal plain as well. Finally, we quantify the amount of sediments required to elevate the surface to MHW plus minimum and maximum IPCC 21st century sea-level rise predictions (RCP2.6 and RCP8.5; Church et al., 2013). In addition, we use previously estimated annual subsidence rates of the peat area (Van der Meulen et al., 2007), and added the volume created by this subsidence to the total amount of required sediments. Furthermore, we discuss the potential of future sediment delivery based on past processes.

\section{Method}

In 2006, TNO - Geological Survey of the Netherlands initiated the GeoTOP modelling program, which delivers and maintains a detailed, national 3D geological voxel model of the shallow subsurface (Stafleu et al., 2011; Van der Meulen et al., 2013). The model was recently extended towards the south-eastern part of the country and reaching a coverage of $28605 \mathrm{~km}^{2}$ (about $70 \%$ of the total land surface area; Fig. 2). For the coastal plain, only the reclaimed Flevoland province is missing and is consequently not used in this analysis.

GeoTOP schematizes the shallow subsurface in millions of rectangular blocks (voxels, tiles or 3D grid cells) each measuring $100 \times 100 \times 0.5 \mathrm{~m}(x, y, z)$ up to a depth of $50 \mathrm{~m}$ b.m.s.l. Each voxel in the model has most likely estimates of the stratigraphical unit (layer) the voxel belongs to and the lithological class that is representative for the voxel (Fig. 2b). These estimates are calculated using stochastic techniques that allow the construction of multiple, equally probable, 3D realisations of the model as well as an evaluation of model uncertainty (Stafleu et al., 2011).

The simple and straightforward data structure of the GeoTOP voxel model allows for easy querying and analysis. Volume calculations can be performed by selecting and counting voxels that meet certain criteria. In this paper, we use volume calculations to estimate the volume of tidal system (Naaldwijk Fm., Walcheren Mb.), Rhine fluvial system (Echteld Fm.) and lithological classes within these units, and anthropogenic deposits.

We use GeoTOP to estimate the amount of present-day and projected accommodation space by calculating the difference in the height of the uppermost voxels and chosen reference planes. For reference planes, the IPCC RCP2.6 and RCP8.5 scenarios were taken as minimum and maximum end of 21st century MSL: +0.26 and $0.82 \mathrm{~m}$ (Church et al., 2013). Furthermore, we follow Jelgersma et al. (1993), who stated aggradation to MHW as a safe scenario for coastal plains under threat of subsidence and sea-level rise. For MWH, we assume an average tidal amplitude of $2 \mathrm{~m}$ for the entire Netherlands' shoreline, which in reality ranges from $3.5 \mathrm{~m}$ in the southwest, to $1.4 \mathrm{~m}$ in the west, to $2.8 \mathrm{~m}$ in the northeast (Vos et al., 2015). This tidal range was added to the RCP2.6 and RCP8.5 scenarios.

In total, $9.07 \mathrm{~km}^{3}$ of peat remains in the shallow coastal plain subsurface (mean bottom depth of $4.3 \mathrm{~m}$ m.s.l.) (TNOGSN, 2019). Van der Meulen et al. (2007) estimated that 9.4 to 28 million $\mathrm{m}^{3} \mathrm{yr}^{-1}$ of additional accommodation space is created by oxidation and compression of these shallow peat layers. Although rates of future peat oxidation and compression are not easy to estimate, as they depend on unknown choices in future groundwater management (Koster et al., 2018), we use these maximum oxidation and compression rates and added these to the provisioned accommodation space by the scenarios of 21 st century MHW.

\section{Results}

The tidal system delivered a net total of $45.30 \mathrm{~km}^{3}$ sediments to the Dutch coastal plains during the past ca. 3000 years, and the Rhine river system a net total of $20.18 \mathrm{~km}^{3}$ during 8000 years (Fig. 3a). The average storage rate of the tidal system is 150 million $\mathrm{m}^{3} \mathrm{yr}^{-1}$ and the fluvial system 2.5 million $\mathrm{m}^{3} \mathrm{yr}^{-1}$. This means that two orders of magnitude more sediments were deposited per year in the tidal systems than in the Rhine river system. Storage is net deposition, i.e., the sum of sedimentation and erosion that occur intermittently in the types of depositional environments at hand. Anthropogenic deposits account for $3.59 \mathrm{~km}^{3}$, substantially less than natural sediment, but the bulk of this volume emplaced after WW-II, in a fraction of the time represented in natural Holocene deposits.

The sand fraction encompasses $52 \%$ of the total sediment load of the tidal system and $29 \%$ of the fluvial system. The majority of the sand fraction deposited by the tidal system is fine grain sand, and medium grained sand is the dominant fraction of the fluvial system (Fig. 3b).

The total volume of this study shows a slight discrepancy between the volume documented by Erkens et al. (2006). This is most likely due to differences in the areal extent of deposits defined as "fluvial" between both studies, as the lateral boundaries of fluvial deposits are diffuse and sometimes unclear where they interfinger with tidal deposits. Nevertheless, both studies find that approximately one third of the sediment consist of sand.

To elevate the coastal surface to present day MSL, $10.37 \mathrm{~km}^{3}$ of sediments is required, whereas $16.98 \mathrm{~km}^{3}$ is needed to elevate to MHW. The amount of sediments to raise 


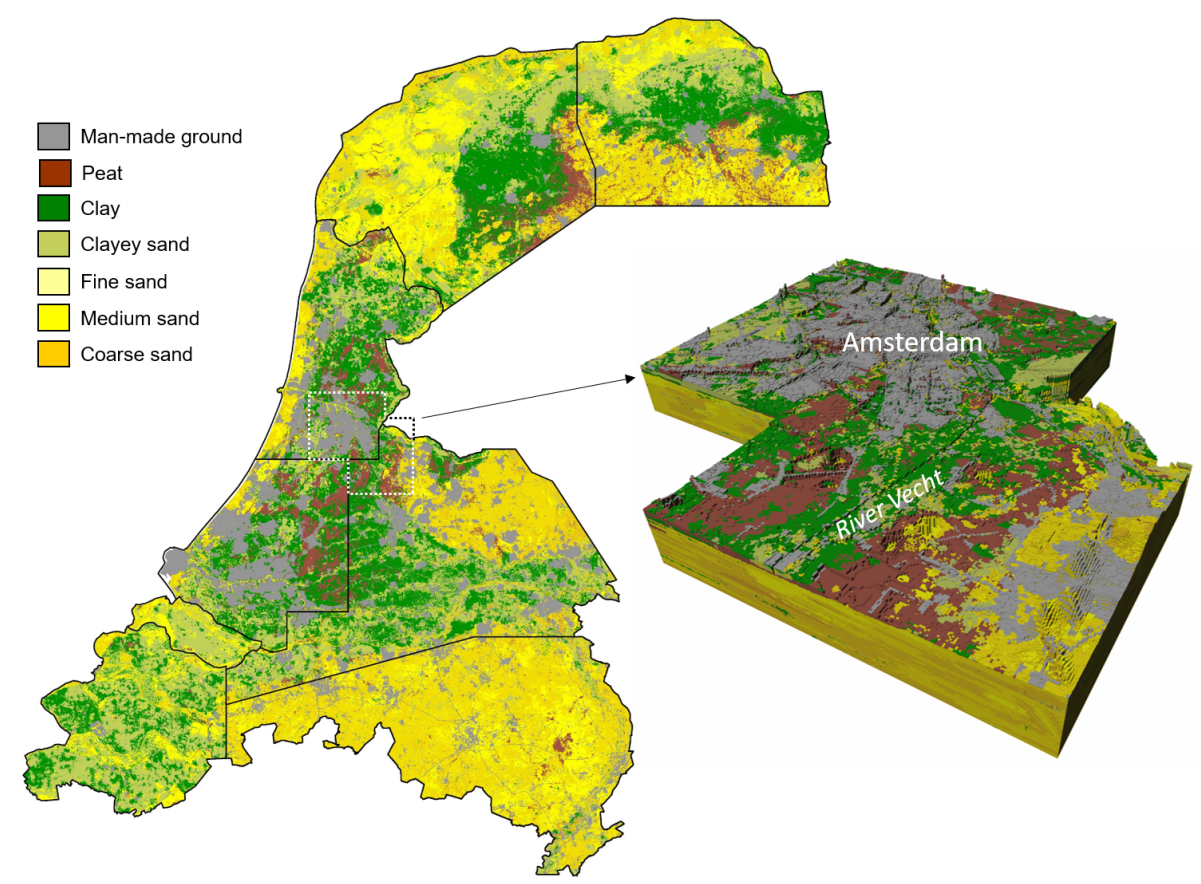

Figure 2. Overview of the GeoTOP 3D geological subsurface model (CTNO Geological Survey of the Netherlands) with (a). The eight areas modelled so far, and (b). A detailed 3D example of a part of the coastal plain exemplifying its lithology. Man-made ground primarily encompasses anthropogenic deposits.

the surface to RCP2.6 and RCP8.5 MHW including forecasted subsidence are 22.41 and $29.29 \mathrm{~km}^{3}$ respectively.

\section{Discussion}

This study merely provides an overview of bulk quantities in past delivered sediments. Beside the physical possibility of controlled sedimentation to counteract subsidence by elevating the surface, it is questionable whether this is eligible from a socioeconomic point-of-view. For instance, inundation means years of land loss (see below), potential salt water intrusion (Oude Essink et al., 2010), and anthropogenic deposition will drastically alter the landscape. Nevertheless, the presented quantities are useful as a first assessment of the possibility of controlled sedimentation to elevate the surface.

Controlled sedimentation for the entire area at once is futile, as this would take centuries to millennia to complete. Despite of this, it might be feasible for smaller designated areas proximal to tidal inlets with high sediment yield.

At present, the volume of anthropogenic deposits emplaced in the coastal plain is insufficient to elevate it to safe levels in its entirety. But human deposition has the advantage that it does not require inundation and that the geomechanical properties can be controlled. Natural deposition in tidal systems ("silting up") are bound to be more fine-grained and therefore compactable than the sand that man would emplace.

\subsection{Learning from the past}

During the recent past, the Netherlands experienced numerous unwanted embankment breaches, which delivered sediments to the subsided peatlands and locally raised the surface. These processes led to a coastal plain with differential elevations, owing to differential duration and magnitude of embankment breaches (Fig. 4). These past situations are very valuable to determine the effects of controlled sedimentation to designated areas of the coastal plain.

Embanking the Dutch coastal plains regionally resulted in increased storm-surge levels. Rather than spreading and attenuation over large areas, water now surged against the embankments, weakening them and locally breached them (Vos, 2015). After breaching, sea water re-entered he peatlands every tidal cycle. This created large channels which inhibited the recovery of the embankments and allowed long-term sediment delivery. Examples are the Braakman (1404 and $1421 \mathrm{CE}$ ), Reimerswaal (1530 and $1532 \mathrm{CE}$ ) and the Dollard $(1509 \mathrm{CE})$. Semi-controlled floods by means of military inundations have also led to long-term loss of land (e.g. Saeftinghe $1583 \mathrm{CE}$; see Fig. 1a for locations).

Centuries of sedimentation were required to infill accommodation space to MHW at that time, before such lands could be reclaimed in the 20th century. The rate of the infilling strongly depended on the availability of sediments, which varied between the different individual tidal systems (Vos, 2015). Furthermore, peat compression by delivered sediments increased accommodation space during the pro- 


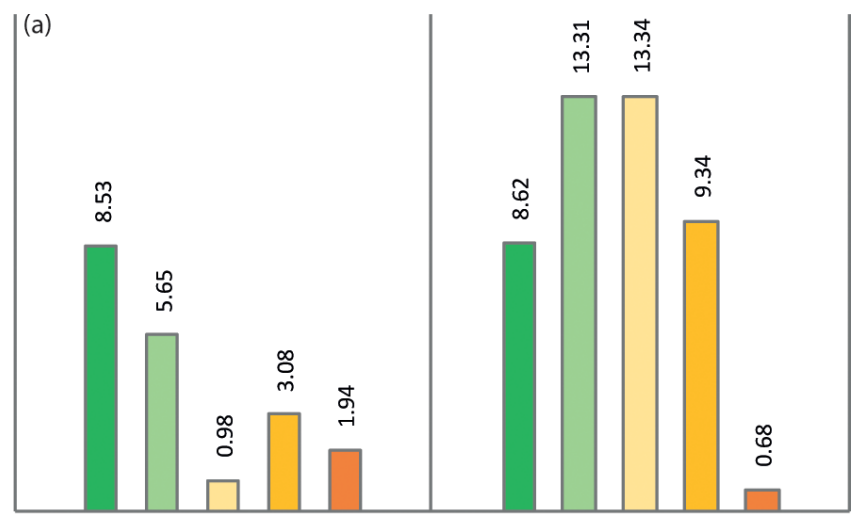

FLUVIAL SYSTEM

TIDAL SYSTEM

$\square$ Clay $\square$ Sandy clay, clayey sand $\square$ Fine sand $\square$ Medium sand $\square$ Coarse sand, gravel

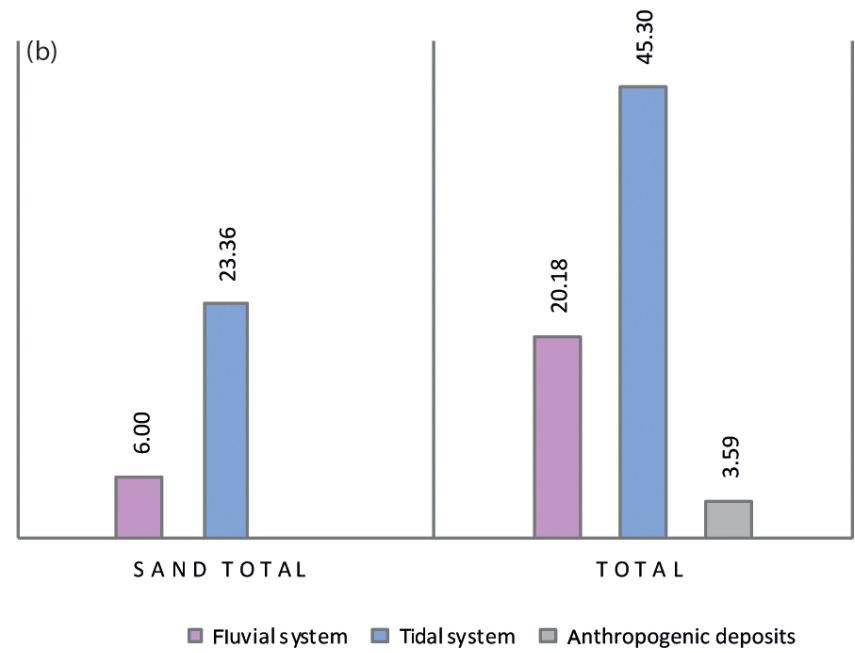

Figure 3. (a) Summary of the lithology of the sediments delivered by the fluvial Rhine system and the tidal systems. (b) Accumulated sand and total sediments brought by both systems and anthropogenic deposits.

cess of infilling (Fig. 4). Controlled sedimentation by natural systems might therefore only work in areas proximal to tidal inlets with high sediment yields and with minimal amount of uncompressed peat layers, like the Westerschelde and Dollard system (Fig. 1a).

Smart design of engineering infrastructures could also enhance sedimentation. For instance, Elias et al. (2012) quantified that net 600 million $\mathrm{m}^{3}$ of sediments were stored in the western Wadden Sea during 80 years after the construction of a large dam that separates the area from Lake IJssel (Fig. 1a, b). These sediments were net transported landwards, but never reached the coastal plain as embankments restrict high water to enter the land.

An alternative approach inspired by past systems is temporarily turning parts of the lowered land into peatlands and allow these peatlands to raise. The low sediment supply inherent to the natural tidal and river systems in the Nether-
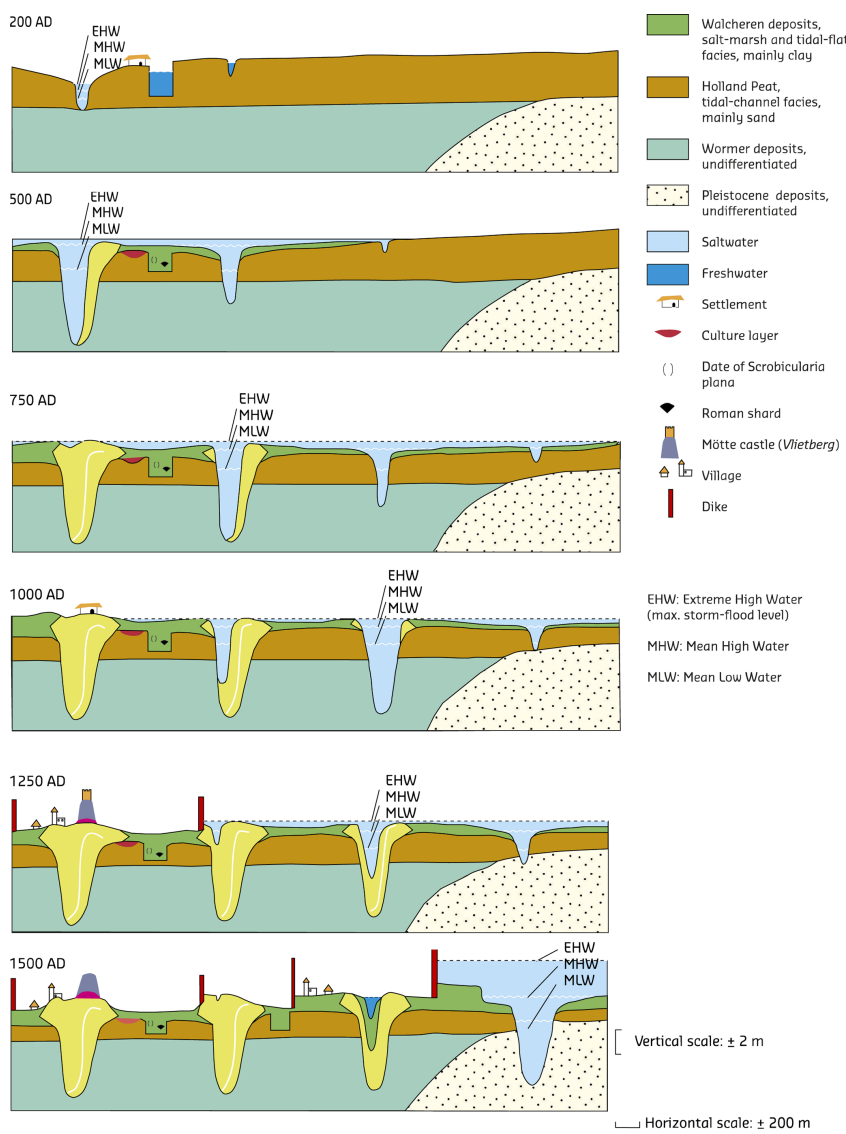

Figure 4. Schematic cross-section illustrating the interplay between tidal channels, embankments, subsidence, and water levels (from Vos, 2015).

lands gave way to widespread peat formation in the past (Erkens, 2009), filling accommodation space that did not receive enough sediment and would otherwise have flooded. This solution will not result in land suitable for modern agriculture or urbanization, but would allow for nature development, and also serve as a carbon sink (Chmura et al., 2003).

\subsection{Anthropogenic deposits}

Emplacing sand to counteract subsidence is at present perhaps a more viable option than sedimentation from water courses. Sufficient sand supplies are located on the inland part of the coastal plain. For instance, Maljers et al. (2015) quantified with GeoTOP for a $40 \times 40 \mathrm{~km}$ area in the upstream part of the Rhine river delta plain that ca. $12 \mathrm{~km}^{3}$ of coarse sand and gravel are available between 10 to $30 \mathrm{~m}$ below the surface, of which $62 \%$ are actually physically exploitable. A more robust analysis conducted by Van der Meulen et al. (2005) showed that down to $50 \mathrm{~m}$ below the surface some $520 \mathrm{~km}^{3}$ of coarse sand and gravel are available, of which maximum $240 \mathrm{~km}^{3}$ are actually exploitable. Circa $20 \%$ of these sediments are situated below the coastal 
plain and are evidently not suitable for mining. This means that onshore sand supplies exceed accommodation space provisioned by subsidence with a factor 4 to 5 .

Also offshore sand can be exploited. At present, offshore sand supplies are being mapped, which are expected to yield high volumes (Maljers et al., 2010). On a small scale these sand recourses have been deployed for decades. However, exploitation of large volumes is challenging as it damages ecosystems, hinders infrastructures, and windfarms.

Combining natural and anthropogenic sedimentation would also be a viable option. The best-known example of this is coastal nourishment; putting dredged sand in areas where waves and currents take care of its emplacement.

\section{Conclusions}

We assessed controlled, i.e., forced natural and anthropogenic, deposition as a measure to elevate the subsiding coastal plain of the Netherlands to saver levels, i.e. equaling predicted future MHW. We focused on sedimentation from tidal systems and the Rhine river fluvial system to fill accommodation space. Our main conclusions are:

Projected accommodation space for IPCC scenarios RCP2.6 and RCP8.5 superimposed on MHW and subsidence will be 22.41 and $29.29 \mathrm{~km}^{3}$ respectively at the end of the 21 st century.

The tidal systems delivered $45.30 \mathrm{~km}^{3}$ of sediments to the coastal plains of the Netherlands or 150 million $\mathrm{m}^{3} \mathrm{yr}^{-1}$, whereas the Rhine river system delivered $20.18 \mathrm{~km}^{3}$ or 2.5 million $\mathrm{m}^{3} \mathrm{yr}^{-1}$. Sand from the tidal systems is most abundant and therefore its deployment is most feasible to counteract subsidence during controlled sedimentation.

Most viable option for controlled sedimentation will be inundating designated areas proximal to tidal areas with a high sediment yield. This option would take centuries to have volumetrically significant results.

Anthropogenic deposits comprise $3.59 \mathrm{~km}^{3}$, the capacity of man to emplace allows us to theoretically keep up with subsidence and sea-level rise

Data availability. Research data are accessible via the online data portal of TNO - Geological Survey of the Netherlands: available at: https://www.dinoloket.nl/en (last access: November 2019), (TNOGSN, 2019).

Author contributions. JS conducted selections on GeoTOP. All the authors contributed to interpretation of the results and writing of the manuscript.

Competing interests. The authors declare that they have no conflict of interest.
Special issue statement. This article is part of the special issue "TISOLS: the Tenth International Symposium On Land Subsidence - living with subsidence". It is a result of the Tenth International Symposium on Land Subsidence, Delft, the Netherlands, 17-21 May 2021.

Acknowledgements. We thank Gilles Erkens for his thorough review. This contribution benefitted greatly from his comments.

\section{References}

Auerbach, L. W., Goodbred, S. L., Mondal, D. R., Wilson, C. A., Ahmed, K. R., Roy, K., Steckler, M. S., Small, C., Gilligan, J. M., and Ackerly, B. A.: Flood risk of natural and embanked landscapes of the Gnages-Brahmaputra tidal delta inlet, Nat. Clim. Change, 5, 153-157, 2015.

Blum, M. D. and Roberts, H. H.: Drowning of the Mississippi delta due to insufficient sediment supply and global sea-level rise, Nat. Geosci., 2, 488-491, 2009.

Chmura, G. L., Anisfeld, S. C., Cahoon, D. R., and Lynch, J. C.: Global carbon sequestration in tidal, saline wetlands soils, Global Biogeochem. Cy., 17, 1-12, 2003.

Church, J. A., Clark, P. U., Cazenave, A., Gregory, J. M., Jevrejeva, S., Levermann, A., Merrifield, M. A., Milne, G. A., Nerem, R. S., Nunn, P. D., Payne, A. J., Pfeffer, W. T., Stammer, D., and Unnikrishnan, A. S.: Sea level change, in: Climate Change 2013: The physical science basis, Contribution of Working Group I to the Fifth Assessment Report of the IPCC, 1137-1216, 2013.

Dixon, T. H., Amelung, F., Ferretti, A., Novali, F., Rocca, F., Dokka, R., Sella, G., Kim, S. W., Wdowinski, S., and Whitman, D.: Subsidence and flooding in New Orleans, Nature, 441, 587-588, 2006.

Elias, E. P. L., Van der Spek, A. J. F., Wang, Z. B., and De Ronde, J.: Morphodynamic development and sediment budget of the Dutch Wadden Sea over the last Century, Neth. J. Geosc., 91, 293-310, 2012.

Erkens, G., Cohen, K. M., Gouw, M. J. P., Middelkoop, H., and Hoek, W. Z.: Holocene sediment budgets of the Rhine Delta (The Netherlands): a record of changing sediment delivery, IAHS, 306, 406-415, 2006.

Erkens, G.: Sediment dynamics in the Rhine catchment, Quantification of fluvial response to climate change and human impact, PhD dissertation Utrecht University, 278 pp., 2009.

Hijma, M. P., Shen, Z., Törnqvist, T. E., and Mauz, B.: Late Holocene evolution of a coupled, mud-dominated delta plainchenier plain system, coastal Louisiana, USA, Earth Surf. Dynam., 5, 689-710, https://doi.org/10.5194/esurf-5-689-2017, 2017.

Jelgersma, S., Van der Zijp, M., and Brinkman, R.: Sealevel rise and the coastal lowlands in the developing world, J. Coast. Res., 9, 958-972, 1993.

Jevrejeva, S., Moore, J. C., and Grindsted, A.: Sea level projections to AD 2500 with a new generation of climate change scenarios, Global Planet. Change, 80, 14-20, 2012.

Koster, K., Stafleu, J., and Stouthamer, E.: Differential subsidence in the urbanized coastal-deltaic plain of the Netherlands, Neth. J. Geosc., 97, 215-227, 2018. 
Li, C., Fan, D., Deng, B., and Korotaev, V.: The coasts of China and issues of sea level rise, J. Coast. Res., 43, 36-46, 2004.

Maljers, D. Stafleu, J., and Vonhögen L.: Uitbreiding van het delfstoffeninformatie systee voor het NCP, Deltares report, 1203426000, 25 pp., 2010 (in Dutch).

Maljers, D., Stafleu, J., Van der Meulen, M. J., and Dambrink, R. M.: Advances in constructing regional geological voxel models, illustrated by their application in aggregate resource assessments, Neth. J. Geosc., 94, 257-270, 2015.

Oude Essink, G. H. P., Van Baaren, E. S., and De Louw, P. G. B.: Effects of climate change on coastal groundwater systems: a modelling study in the Netherlands, Water Resour. Res., 46, 1-16, 2010.

Reed, D. J.: Patterns of sediment deposition in subsiding coastal salt marshes, Terrebonne Bay: the role of winter storms, Estuar. Coast., 12, 222-227, 1989.

Rovira, A. and Ibañez, C.: Sediment management options for the lower Ebro River and its delta, J. Soil. Sediment., 7, 285-295, 2007.

Stafleu, J., Maljers, D., Gunnink, J. L., Menkovic, A., and Busschers, F. S.: 3D modeling of the shallow subsurface of Zeeland, the Netherlands, Neth. J. Geosc., 90, 293-310, 2011.

Syvitski, J. P. M., Kettner, A. J., Overeem, I., Hutton, E. W. H., Hannon, M. T., Brakenridge, G. R., Day, J., Vörösmarty, C., Saito, Y., Giosan, L., and Nicholls, R. J.: Sinking deltas due to human activities, Nat. Geosci., 2, 681-686, 2009.

Tang, Q., Oki, T., Kanae, S., and Hu, H.: Hydrological cycles change in the Yellow River basin during the last half of the twentieth century, J. Climate, 21, 1790-1806, 2008.

Terpsta, S., Zbinden, S., Knip, C., and Schunck, R.: Quick scan alternatieve veiligheidsmaatregelen, Twynstra Grudde, 441245/SZB/MSD, Amersfoort, 154 pp., 2007 (in Dutch).
TNO-GSN: Online portal for digital geo-information in the Netherlands, available at: https://www.dinoloket.nl/en, last access: November 2019.

Van der Meulen, M. J., Van Gessel, S. F., and Veldkamp, J. G.: Aggregate recources in the Netherlands, Neth. J. Geosc., 84, 376387, 2005.

Van der Meulen, M. J., Rijnveld, M., Gerrits, L. M., Joziasse, J., Van Heijst M. W. I. M., and Gruijters, S. H. L. L.: Handling sediments in Dutch river management: The planning stage of the Maaswerken river widening project, J. Soil. Sediment., 6, 163172, 2006.

Van der Meulen, M. J., Van der Spek, A. J. F., De Lange, G., Gruijters, S. H. L. L., Van Gessel, S. F., Nguyen, B.-L., Maljers, D., Schokker, J., Mulder, J. P. M., and Van der Krogt, R. A. A.: Regional sediment deficits in the Dutch lowlands: implications for long-term land-use options, J. Soil. Sediment., 7, 9-16, 2007.

Van der Meulen, M. J., Doornenbal, J. C., Gunnink, J. L., Stafleu, J., Schokker, J., Vernes, R. W., Van Geer, F. C., Van Gessel, S. F., Van Heteren, S., Van Leeuwen, R. J. W., Bakker, M. A. J., Bogaard, P. J. F., Busschers, F. S., Griffioen, J., Gruijters, S. H. L. L., Kiden, P., Schroot, B. M., Simmelink, H. J., Van Berkel, W. O., Van der Krogt, R. A. A., Westerhoff, W. E., and Van Daalen, T. M.: 3D Geology in a 2D country: perspectives for geological surveying in the Netherlands, Neth. J. Geosc., 92, 217-241, 2013.

Vos, P. C.: Origin of the Dutch coastal landscape, $\mathrm{PhD}$ dissertation, Utrecht Univerity, 359 pp., 2015.

Walling, D. E.: Human impact on land-ocean sediment transfer by the world's rivers, Geomorphology, 79, 192-216, 2006.

Waterman, R.: Integrated coastal policy via building with nature, in: Proc. of the first int. meeting Cities on water, Venice, 11-13 December 1989, 64-74, 1991. 